\title{
PENGARUH MOTIVASI BELAJAR TERHADAP PRESTASI (STUDI KASUS TENTANG PEMBELAJARAN MANDIRI MATA KULIAH MATEMATIKA EKONOMI DAN BISNIS
}

\author{
Putri Kemala Dewi Lubis ${ }^{1)^{*}}$ \\ ${ }^{1)}$ Fakultas Ekonomi, Universitas Negeri Medan \\ ${ }^{*}$ Penulis Korespondensi: puputdewilubis@gmail.com
}

\begin{abstract}
Penelitian ini bertujuan untuk mengetahui Bagaimana motivasi mahasiswa kelas B semester satu Prodi Pendidikan Akuntansi tentang pembelajaran mandiri pada mata kuliah matematika ekonomi. Penelitian ini menggunakan metode kuantitatif dengan angket dan dokumentasi sebagai metode pokok, sedangkan observasi sebagai metode pendukung. Subjek penelitian sebanyak 33 responden dan merupakan penelitian populasi. Data yang diperoleh dari angket dan dokumentasi kemudian dianalisis dengan menggunakan metode kuntitatif dengan menggunakan regresi linier sederhana. Hasil pengujian hipotesis menunjukkan bahwa nilai thitung lebih besar dari nilai t-tabel dengan tingkat signifikansi 0,05. Nilai t-hitung sebesar 2,895 sedangkan nilai t-tabel sebesar 2,042 (2,895 > 2,042) maka Ho ditolak artinya bahwa ada pengaruh yang positif antara motivasi belajar dengan prestasi belajar secara mandiri pada mahasiswa pendidikan akuntansi.
\end{abstract}

Keyword : Motivasi belajar, prestasi, pembelajaran mandiri 


\section{PENDAHULUAN}

Sistem belajar mandiri merupakan sistem pembelajaran yang didasarkan pada disiplin terhadap diri sendiri yang dilakukan oleh mahasiswa dan disesuaikan dengan keadaan perorangan mahasiswa yang meliputi antara lain kemampuan, kecepatan belajar, kemauan, minat, waktu yang dimiliki, dan keadaan sosial ekonominya. Mahasiswa banyak mengalami kesulitan dalam mempelajari materi ajar mata kuliah matematika ekonomi. Kebanyakan mahasiswa mengalami kesulitan dalam mata pelajaran matematika ekonomi, mengingat banyaknya materi yang sulit, kurangnya waktu tatap muka, media penunjang kurang dan kurang jelasnya penjabaran materi di modul oleh karena itu masih banyak materi yang belum dapat dikuasai oleh mahasiswa. Tentunya hal tersebut akan mempengaruhi motivasi mahasiswa terhadap proses pembelajaran mandiri. Motivasi adalah dorongan yang timbul dari diri seseorang untuk melakukan suatu hal. Menurut Mc. Donald, motivasi adalah perubahan energy dalam diri seseorang yang ditandai dengan munculnya "feeling" dan didahului dengfanb tanggapan terhadap adanya tujuan. Sedangkan menurut A.M. Sardiman (2009: 75) motivasi belajar diartikan sebagai serangkaian usaha untuk menyediakan kondisi-kondisi tertentu, sehingga seseorang mau dan ingin melakukan sesuatu, dan bila ia tidak suka, maka akan berusaha untuk meniadakan atau mengelak perasaan tidak suka itu.

Pelaksanaan pembelajaran mandiri yang menarik dan inovatif, ditambah dengan
JURNAL NIAGAWAN Vol 6 No 2 Oktober 2017 pelengkapan media penunjang yang memadai dan disusunnya materi modul yang disesuaikan dengan kebutuhan mahasiswa akan memberikan dampak positif terhadap motivasi belajar sehingga mahasiswa akan antusias mengikuti pembelajaran mandiri. Bila hal itu terlaksana dengan baik, maka tujuan yang ingin dicapai pada pembelajaran mandiri akan berpengaruh terhadap motivasi belajar sehingga mahasiswa tertarik untuk lebih meningkatkan prestasi belajarnya.

Ketika kegiatan belajar mengajar berlangsung, jarang sekali seorang dosen mengetahui siswanya mempunyai motivasi atau tidak dalam mempelajari mata kuliah matematika ekonomi yang sedang diajarkannya. Sehingga pada saat ujian berlangsung terdapat beberapa mahasiswa yang belum mampu menjawab pertanyaanpertanyaan yang berhubungan dengan mata kuliah tersebut. Jika terdapat mahasiswa yang kurang termotivasi belajar maka secara langsung dapat mempengaruhi kepada hasil belajarnya.

Menurut Muhibbin Syah (2000: 136) bahwa belajar adalah tahapan perubahan seluruh tingkah laku individu yang relative menetap sebagai hasil pengalaman dan interaksi dengan lingkungan yang melibatkan proses kognitif. Begitu juga menurut James Whitaker yang dikutip oleh Wasty Soemanto (1990: 98-99), belajar adalah proses dimana tingkah laku ditimbulkan atau diubah melalui latihan dan pengalaman. Menurut Winkel melalui Sunarto (1996: 162) mengatakan bahwa "prestasi belajar adalah suatu bukti keberhasilan belajar atau kemampuan seorang 
siswa dalam melakukan kegiatan belajarnya sesuai dengan bobot yang dicapainya." Hipotesis yang digunakan dalam penelitian ini adalah " ada pengaruh yang posistif antara motivasi belajar terhadap prestasi mahasiswa pada mata kuliah matematika ekonomi" Kerangka berpikir dalam penelitian ini digambarkan sebagai berikut :

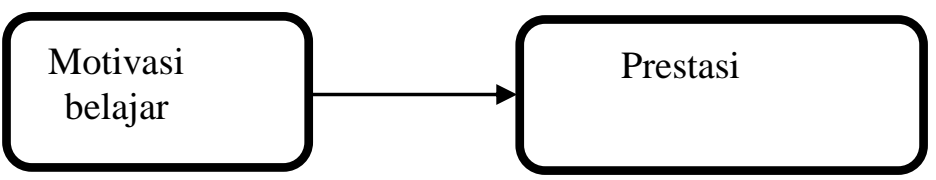

\section{METODE PENELITIAN}

Pendekatan yang digunakan dalam penelitian ini adalah pendekatan kuantitatif yaitu mendeskripsikan data apa adanya dan menganalisis data angket mahasiswa dengan kalimat-kalimat penjelasan secara kuantitatif. Populasi dalam penelitian ini adalah seluruh mahasiswa kelas B semester satu Prodi Pendidikan Akuntansi yang mengikuti kuliah matematika ekonomi berjułmlah 33 orang. Sampel adalah bagian dari jumlah dan karakteristik yang dimiliki oleh populasi tersebut (Sugiyono, 2012: 80). Sampel adalah sebagian atau wakil populasi yang diselidiki. Dalam menentukan sampel bahwa apabila subyeknya kurang dari 100 lebih baik diambil semua dan apabila subyeknya lebih dari 100 dapat diambil $10 \%-15 \%$ atau $20 \%-25 \%$ (Arikunto: 1996: 120). Pada penelitian ini tidak menggunakan sampel dikarenakan jumlah subjek penelitian kurang dari 100 untuk itu subjek yang diteliti diambil semua sehingga merupakan penelitian populasi.
JURNAL NIAGAWAN Vol 6 No 2 Oktober 2017

Teknik pengumpulan data yang dilakukan dengan cara observasi dan menyebarkan angket. tehnik pengumpulan datanya yang bersifat kuisioner atau angket skala motivasi siswa. Tujuan penggunaan kuisioner dalam kegiatan pengajaran adalah untuk memperoleh gambaran mengenai latar belakang mahasiswa sebagai bahan dalam menganalisis tingkah laku hasil dan proses belajarnya yang dicapainya dan proses belajar yang ditempuhnya.

Variabel dalam penelitian ini menggunakan variabel operasional motivasi belajar sebagai variabel independen dan prestasi sebagai variabel dependen. Teknik analisis data menggunakan regresi linier sederhana, dengan melakukan uji normalitas, uji linieritas, uji asusmsi klasik dan analisis regresi linier berganda, model bersamaan regresi linier berganda sebagai berikut:

$$
\mathbf{Y}=\mathbf{a}+\boldsymbol{\beta} \mathbf{X}
$$

\section{Keterangan:}

$\mathrm{Y}=$ Variabel Prestasi Mahasiwa

$\mathrm{i} \mathrm{a}=$ Faktor intercept/konstanta

$\beta=$ koefisien regresi

$\mathrm{X}=$ Variabel motivasi belajar

\section{HASIL DAN PEMBAHASAN}

Berdasarkan hasil analisa data maka persamaan regresi linier sederhana sebagai berikut : $\mathbf{Y}=\mathbf{5 4 , 2 1 4}+\mathbf{0 , 6 7 6} \mathrm{X}$, dari hasil regresi linier dapat disimpulkan bahwa konstanta sebesar 54,214 artinya jika motivasi belajar mahasiwa tentang pembelajaran mandiri pada mata kuliah matematika ekonomi nilainya adalah 0 , maka prestasi belajar 
sebesar 54,214. Koefisien regresi variabel motivasi belajar sebesar 0,676 artinya jika motivasi belajar pembelajaran mandiri mengalami kenaikan 1, maka prestasi belajar mahasiswa akan mengalami peningkatan sebesar 0,676. Koefisien bernilai positif artinya terjadi hubungan yang positif antara motivasi belajar dengan prestasi mahasiswa. Semakin tinggi motivasi belajar secara mandiri pada mata kuliah matematika ekonomi akan semakin meningkatkan prestasi hasil belajar mahasiswa semester satu prodi pendidikan akuntansi.

Pengujian hipotesis yang dilakukan menunjukkan nilai t-hitung sebesar 2,895 sedangkan nilai t-tabel sebesar 2,042. Jika nilai t-hitung > t-tabel $(2,895>2,042)$ maka Ho ditolak artinya bahwa ada pengaruh yang positif antara motivasi belajar dengan prestasi mahasiswa pendidikan akuntansi tentang pembelajaran mandiri. Hasil penelitian sesuai dengan menurut Sardiman (2007;75) Mengemukakan bahwa motivasi belajar adalah: keseluruhan daya penggerak di dalam diri siswa yang menimbulkan kegiatan belajar, yang menjamin kelangsungan dari kegiatan belajar dan yang memberi arah pada kegiatan belajar sehingga tujuan yang dikehendaki oleh subjek belajar dapat tercapai." Prestasi belajar menunjukkan tingkat kemampuan yang dimiliki oleh mahasiswa dalam menerima, memahami, mengolah dan menilai informasiinformasi yang diperoleh dalam proses belajar mengajar. Keberhasilan seorang mahasiswa dalam proses belajar dapat diukur atau dilihat dengan indeks prestasi kumulatif mahasiswa. Dimana indeks prestasi kumulatif merupakan
JURNAL NIAGAWAN Vol 6 No 2 Oktober 2017 angka yang menunjukkan prestasi atau keberhasilan studi mahasiswa dari semester pertama sampai dengan semester terakhir yang telah ditempuh secara kumulatif.

\section{KESIMPULAN DAN SARAN}

Tanggapan responden tentang komponen dari motivasi belajar mahasiswa akuntansi dapat dikatakan baik. Hal ini dapat dilihat dari tanggapan positif dari tiap responden terhadap indikator-indikator seperti durasi kegiatan belajar secara mandiri, frekuensi kegiatan belajar, persentesinya (ketepatan dan kelekatannya) pada tujuan kegiatan belajar, keuletan dan kemampuan dalam menghadapi rintangan dan kesulitan untuk mencapai tujuan belajar, dan pengorbanan, tingkatan aspirasinya yang hendak dicapai dengan kegiatan yang dilakukan, tingkatan kualifikasi prestasi, dan arah sikapnya terhadap sasaran kegiatan belajar dapat dilihat dari adanya hubungan yang positif antara motivasi belajar dengan prestasi mahasiswa prodi pendidikan akuntansi pada mata kuliah matematika ekonomi, hal ini dapat dilihat dari hasil pengujian hipotesis dengan nilai t-hitung $>\mathrm{t}$ - tabel $(2,895>2,042)$ artinya bahwa ada pengaruh yang positif antara motivasi belajar dengan prestasi mahasiswa pendidikan akuntansi tentang pembelajaran mandiri. 


\section{REFERENSI}

Desmita. 2010. Psikologi Perkembangan Peserta Didik. Bandung: PT Remaja Rosdakarya.

Hasbullah. 1999. Dasar-dasar Ilmu Pendidikan. Jakarta: PT Raja Grafindo Persada.

Koeswara. 1989. Motivasi (Teori dan Penelitiannya). Bandung: Angkasa Bandung.

Mulyani, 2005. Psikologi Belajar. Yogyakarta: CV. Andi Offset.

Purwanto, Ngalim. 2011. Psikologi Pendidikan. Jakarta: Remaja Rosdakarya
JURNAL NIAGAWAN Vol 6 No 2 Oktober 2017 Sardiman, 2007, Interaksi dan Motivasi

Belajar Mengajar, Jakarta, PT Raja Grafindo Persada

Suciati dan Prasetya Irawan, 2005, Teori Belajar dan Motivasi, Cetakan Kelima, Jakarta; PAU-PPAI, Universitas Terbuka

Sugiyono, 2012. Metode Penelitian Kuntitatif Kualitatif dan R\&D. Bandung: CV Alfabeta. 